\title{
Anthropological contributions for thinking and acting in the health area and its ethical dilemas
}

\author{
Contribuições da antropologia para dilemas éticos da área da saúde
}

Maria Cecília de Souza Minayo ${ }^{1}$

${ }^{1}$ Fundação Oswaldo Cruz, Escola Nacional de Saúde Pública, Claves. Av. Brasil 4036/700, Manguinhos. 21040-361 Rio de Janeiro RJ.cecília@claves.fiocruz.br
Abstract This paper attempts to analyze the way in which the issue of ethics in social research is dealt by institutional commissions based in biomedicine criteria. This discussion is particularly important for Social Sciences in Health, as our projects must necessarily be presented to Committees for assessment. In actual fact, Resolution $N^{o}$ 196/1996 issued by the National Health Council establishes this mandatory requirement for all social areas. However, there is a question among researchers working with social issues, arguing that the health sector is moving outside its field when attempting to regulate actions in other fields of investigation. Grounded on philosophical anthropology, this paper is divided into three parts: (1) elements of anthropological foundations of ethics; (2) contributions of Anthropology to thinking about ethics and human rights in health; (3) internal and external questioning about anthropological practice. I conclude that if the ethical issue that involves human beings cannot be reduced to the procedures established by Ethics Committees, discussions in greater depth are required among social scientists on the construction of a practice based on and guided by respect for the intersubjectivity of all the players engaged in a research project. Key words Ethics in social research, Ethical grounds of anthropology, Ethics and health
Resumo Neste artigo, busco problematizar a forma como a questão da ética em pesquisa social vem sendo tratada hoje pelas comissões institucionais inspiradas nas questões da biomedicina. Essa discussão é particularmente importante para as Ciências Sociais em Saúde pois existe uma obrigatoriedade de apresentação dos nossos projetos para avaliação dos comitês. A rigor, na concepção da Resolução 196/1996 do Conselho Nacional de Saúde, essa obrigatoriedade cobre todas as áreas sociais. No entanto, existe questionamento dos pesquisadores que lidam com o social, argumentando que o setor saúde extrapola quando tenta regular ações de outros campos de investigação. Fundamentado na antropologia filosófica, este texto se divide em três partes: (1) alguns elementos sobre fundamentos antropológicos da ética; (2) contribuições da Antropologia para pensar a ética e a realização dos direitos humanos em saúde; (3) questionamentos internos e externos sobre a prática antropológica. Concluo dizendo que, se a questão ética que envolve seres humanos não pode se reduzir aos procedimentos demandados por Comissões de Ética, é preciso aprofundar a discussão dos cientistas sociais na construção de uma prática pautada e orientada pelo respeito à intersubjetividade de todos os atores envolvidos numa pesquisa.

Palavras-chave Ética em pesquisa social, Fundamentos éticos da antropologia, Ética e saúde 


\section{Introduction}

Internationally speaking, there is a sufficiently critical mass able to challenge inadequacies of the Ethical Commissions for Biomedical Research with Human Beings when it comes to qualitative research. This disquiet is also dealt with by a researcher who is a member of the Ethical Committee in Research and has written about this inadequacy in her doctorate thesis dissertation ${ }^{1}$. Ethical committees around the world have been created due to the demand, as well as to social and governmental pressure to try to control the means by which knowledge had traditionally been constructed, besides use given to biomedical discoveries. Once the same procedures were used in social researches, it was inevitable that tensions would aroused in terms of inadequacies as to transposed procedures - as one can see from texts by Guerriero ${ }^{1}$,Victora \& Oliven ${ }^{2}$, Social Science and Humanities Research Ethics Special Working Committee: Giving voice to the spectrum ${ }^{3}$, The Indian Committee for Ethics in Social Science Research in Health: ethical guidelines for social research in health ${ }^{4}$, among others.

In this text, I present discussion in four parts:

- Anthropological framework on ethics;

- Possible contributions from Anthropology to ethics (recognition of human rights) in health;

. Internal and external challenges for the anthropological practice;

. Some questions for deeper discussion.

\section{Anthropological framework on ethics}

It would be rather pretentious for me to add something to what has been the focus of discussion. However, following Guerriero's ${ }^{1}$ clues to questions of the area, in this paper, I seek support in the challenges of place, role and responsibility of anthropology in the ethical issue. I speak of anthropology and not of qualitative research, since, to me, the latter is a derivation of anthropological assumptions, only to gain meaning when it goes beyond informants' speeches, and covers the fundamental aspects of human interactions - treated by anthropology.

I try to get away from action normatization of trends - not because they are not important, but because, as I understand, they presuppose a level of approach in which bioethics must be humanistic, treated by philosophical anthropology. This field of knowledge defines the constitution of subjects, as well as of intersubjective rela- tionship as founders of humanism, but in bioethics these concepts are treated differently by pragmatic and principalist approaches, and by those who call themselves personalists and humanists.

Neves ${ }^{5}$ carries out an extensive research on the foundations of Anglo-American and pragmatic bioethics. According to the author, their bases assume a consequentialist position to whom an utilitarian criterion is the only definition of action morality. Neves ${ }^{5}$ states that: a relativist sense arises in Anglo-American ethical reasoning, developing either in casuistic or in situationist ethical terms. Norms for moral conduct are sought to be established, thus contributing to the highlighted success of this perspective in the clinical practice realm. According to Neves, the presence of bioethicicists is routinely seen in North American health institutions - which clearly shows the functionalism and technicalism of bioethics, treated as a subject and an area of knowledge construction in itself. In this type of action normatization, the basis coincides with the norm itself. The "personalist" critique (term used by Neves on the European view) of Anglo-American view is basically held on two main topics: (1) the one-sidedness with which this approach considers the person and (2) the overvaluation of the human being as a rational being, with their own will, which will accentuate their individualistic inclination.

On the other hand, the "personalist and humanistic" view, of phenomelogical, existentialist and hermeneutic origins, is deepened by Gadamer's ${ }^{6}$ comprehension reasoning and by Habermas $^{7}$. It is discussed in Apel' $s^{8}$ argumentative proposal, which places the responsibility of each person for societal aspects at the ethical plain. It is further radicalized with Lévinas "9 ethics of alterity. All the way through these positions, the subject notion is based on the uniqueness of each one's concrete reality and on the universal characteristics of the human kind, leading to the central concept that the subject is only constructed through communication with the OTHER which give rise to an understanding of intersubjectivity as a dimension of subjectivity. In the "personalist" European thought, unity of subjectivity, relatedness of intersubjectivity and societal solidarity are inseparable.

Lévinas ${ }^{9}$ proposes breaking with the idea of subject totality: since, according to him, the subject is not on a pedestal from where they can encompass everything and everyone. Challenging the ontological concept of subject, Lévinas demonstrates that the one-on-one meeting is prior 
to reasoning, and the meeting with the OTHER is prior to the knowledge about oneself. Well, it is this meeting with the OTHER that ask for and conducts to an open dialogue, to infinity, and destroys not only the ontological closure, but also the centrality based on subjectivity (totalitarian and individualistic) in favor of intersubjectivity. Thus, the new Humanism would be the history of each one's uniqueness in this face-to-face relationship: a relationship in which one cannot dissolve the other, but in which the making sense possibility depends of the proximity and understanding of the other. Lévinas further attacks the distancing elements which are so common in positivist sciences: he deepens the idea that in faceto-face meetings, being benevolent is not enough, since openness is necessary, overcoming egotism and the rejection of the other are necessary. The author also reminds us that benevolence without intersubjectivity can sound like the highest expression of domination of the other, as a means of self-projection, whilst keeping the state of over position in relation to the other, who is in a inferior, submissive situation ${ }^{9}$. To summarize, according to Lévinas' thought, it is Ethics, and not Ontology that constitutes the first Philosophy, since it is in the face-to-face relationship that the human being creates all meaning. It is when facing the OTHER that the subject realizes that they are responsible and sympathetic.

Contributions of anthropology

to ethical reasoning in health

The reader will probably have noticed my part pris for the "personalist" and "humanist" roots of bioethics. I understand that when we speak of ethics in health, our central focus is the human being, being the key concepts: the subjectivity oneness, the relatedness character of intersubjectivity and the solidarity in society composing the human fundamental equality which gathers researchers, their interlocutors and any person in society. I understand human fundamental equality as the ability that each one has to think, feel, express themselves and act, each acting logically and based on their own experiences. This is the principle that shows us that we are capable of "being" in intersubjectivity and in our contextualization in and of the world.

In this sense, I argue that the anthropological practice, can, due to their theoretical-methodological tradition, contribute to strengthen intersubjectivity, to broaden the understanding of human problems and to clarify and inform about procedures and practices of the social life. Therefore, I also argue that, under certain conditions, the anthropological practice draws together conditions that enable people to act with ethics and to promote the rights of groups with which researchers act. I will, however, seek to put into perspective this last proposition to the maximum.

Besides all the philosophical and theoretical aspects, one of the most significant contributions of anthropology occurs precisely in its methodological approach. Despite there being, in this field, many theories, methods and anthropological designs, empirical operationalization of researches show elements that are in common, elements that traditionally have guided the researcher in field work or in an understanding anamnesis. From an anthropological point of view, the scientific model used to understand the social world bear the following principles: (a) intersubjectivity: we are considered in relation to others; (b) understanding: in order to target the world in which we live, we need to understand things and social realities as relevant; (c) rationality and internationality: the social world is always composed of actions and interactions that obey uses, customs, rules or that are about the means, the ends and the results ${ }^{10-17}$

For this reason, the anthropological method (a) allows for a criticism of pseudo-objectivism of science, proposing subjectivity as founder of meaning; (b) makes subjectivity relevant as constitutive of the social being and inherent to the scope of objective self-comprehension; (c) places its focus on human experience and on the acknowledgement of the complexity of human relations (d) shows that it is important to value relationships and to understand people in their own social contexts; (e) emphasizes that the production of "truths about people" occurs in faceto-face meetings and through empathy between interlocutors.

Nonetheless, Anthropology also works with the concept of objectivity, as long as we can understand that all objectivity undergoes a subjectivity construction. For this reason, it seeks to (a) explicit the context rationality and the internal logic of the several actors and groups that are being studied; (b) present dynamic analysis of reality; (c) always corroborates that all human beings produce meanings, and plan and project their future; and (d) their conclusions, despite their never being universal-like, allow us to understand peculiar contexts, producing comparisons and the most broadening inferences. 
When we bring the anthropological method to the area of health, we understand that it serves to understand: (a) cultural values and representations; opinions and beliefs about health and ailments; both in biomedical and in traditional terms; (b) the relationships between each of the members of health groups, as well as the patients and their family members; the logic of the health institutions and specific social movements; and (c) evaluation of policies, practices, proposals, systems and attention models, from its formulation, technical application to the relevance that the several subjects ascribe to them ${ }^{18}$.

If we think, for example, of the relationship between a health professional and a patient in anamnesis, anthropologists would advise the former to believe in the narrative provided by their interlocutor as one of the possible versions of their problem: (a) there is logical consistency in the patient's expressions when they describe what they have experienced seeking to give an order to the meanings reported; (b) there is mutual possibility of considerate interpretation (from the health professional and from the part of the patient) in the dialogue construction; and (c) the patient's report could be based on empirical or imaginary reality that goes beyond them, in any case being effective to them. As William Thomas' ${ }^{19}$, himself an anthropologist, theorem goes: "When someone defines their situation as real, it is real in its consequences", thus placing evidence on one of the dilemmas of those who work with people - which is the case of health professionals - i.e., that of overcoming formal and functionalist interpretive schemas.

Anthropology would also teach the health professionals that, methodologically speaking, we need to, first of all, listen to how our interlocutor defines their situation ${ }^{20}$. Secondly, we need to know what their biographical experience is, bearing in mind that each person is always biographically situated in their life world and that it is in such context that they think, feel and act. Thirdly, we need to find out what their stock of knowledge is, i.e., what their sedimentation of experiences and situations lived are - knowing that it is from this knowledge that they interpret the world and support their actions. Fourthly, it is necessary that we ask ourselves what the interlocutor considers relevant in their speech, since their relevance structures are related to the knowledge background and to their biographical situation ${ }^{20}$.

Believing that a relationship between different people that respect each other under the conditions of health professional and patient would be possible, the field of anthropology would also highlight that there is a "reciprocity of perspective, communication, community, objectives and subjective interpretation" 20 - which can always occur in interlocution. For this reason, intersubjectivity would be a central category to understand relationship and for the analyses produced both in clinical and in preventative and promotional processes. According to Schutz ${ }^{20}$ "here where I am - there where my peer is: we can never be in the same place, in the same position, never be both here or there", however, there is a situation of familiarity that is created by means of institutional and personal mechanisms, under the form of " $u s$ ", allowing for the understanding of the other as unique in one's individuality.

\section{Movements that hinder intersubjectivity in health}

Accepting evidences that ailments are not only biological entities since they are also linked, to different extents, to peoples ways of life, to the pluralist treatment offers and cure, to the greater presence of society in the control it exercises on medical and epidemiological interventions make the health field much more open to receive contributions from anthropology. However, it is necessary to bring light to some external and internal movements that once again tend to challenge this interaction.

\section{The biological reductionism}

The first one comes from the ideology that supports contemporary genetics and that takes scientists to return to the dream nourished by bacteriologists of the late nineteenth and early twentieth centuries ${ }^{21}$. Nunes, in a classical work, has analyzed how scientific revolution caused by the discoveries of bacteriology led medical studies to be guided by a reflection of rejection of the social issue, in favor of a technological empire. Ideology created around these discoveries has become reference to Western medicine: (1) an effective "combat" (please note the military terminology!) of acute ailments, by means of immunization and treatment; (2) centralization of actions pertaining to defined biological ailments; (3) optimism in relation to the eradication of epidemics; (4) and the re-organization of medical teaching with a sole focus on the biological field ${ }^{21}$.

It is clear that scientific development enabled by bacteriology was and still is important for the 
human kind. What we put forth in order for all to reflect about in terms of ideas and practice is the rejection of economic, social, cultural and subjective factors of infirmities and health promotion, reducing these phenomena to entities or simply to biological processes, leaving behind a long tradition of social medicine that was fully used during half of the nineteenth century. Today, fragmentation produced by biomedical reductionism leads us to have, inside a hospital, the reduction of a sick person to simply their body, a mere object of manipulation and interventions. Everything is opposed to the proposals of the World Health Organization exposed in the Ottawa Letter and in the Alma Ata Declaration which represent a broadened definition of public health/collective health, founded on the understanding of conditions, situations and life styles.

Again, from the end of the twentieth century, we have been confronted by attempts to think of health as a biologically determined process only. This emerging ideology was researched by the French anthropologist, Lucien $\mathrm{Sfez}^{22}$. He produced an essay on representations of health and illnesses in contemporary American, Japanese and French societies, and he discovered that there is a tendency - which reaches its peak in the American society - to construct an utopian and practical paradigm of perfect health, supported by the development of biology, of pure environment and of technologies for drug production known as fourth generation medicine. $\mathrm{Sfez}^{22}$ states that this project is being constructed by a scientific and technological elite under the protection of powerful economic and financial interests. It takes place in a moment of extraordinary scientific advances in the biological area, especially in the genetic area, in tune with powerful health insurance companies and with the health industry in general. The niche of investment in these researches has produced a true myth of attainment of the perfect health by means of genetic prediction (with the purpose of replacing the concept of illness prevention), as if it were possible to replace will, desire and human action by technological artifacts. This myth has been challenged by important authors even in the area of biology, such as Henry Atlan ${ }^{23}$ in his L'uterus artificiel (in English, The artificial womb).

\section{Clinical and epidemiological technicism}

The second movement that tends to eliminate the historical subject (intersubject and sympathetic) and that is situated in the health area is the technicism of clinic and epidemiology, whose belief that truth is originated from refining the method creates an illusion of number, data and model certainty. They lack "the flesh, the bones and the soul of social life", as Malinowiski ${ }^{24}$ would remind us. Many anthropologists and sociologists have been speaking against this technicist trend which is occurring in many fields. In the health area, bursts aimed at evidencing the truths and objectivity have forgotten to ask fundamental questions and to situate people's problems in the dynamics of the contexts in which they occur, their lives, their relations and their representations. For this reason, technicist studies gather data on the reality, treat infirmities as entities that are external to the patients that suffer, lessening efficacy of the necessary human contacts in the health area. Facing this challenge, the Ethical Committees that base their work on ly on normativeness can do very little because thought philosophy is what divides people in researchers and objects.

\section{Exotism of anthropology}

A third aspect that makes this a difficult interrelation between the health sector - which strictly points to the technique - and anthropology derives from the practice of anthropologists themselves. First of all, many times we have professed a very enclosed reflection, which hinders the access of health professionals to our findings and contributions. However, an even greater difficulty is the one defined by Raynaut ${ }^{25}$ as: How to make the psychological and social sciences admit that the human being is not composed only of a spirit, but also of a body. How to make them admit also that human societies cannot be analyzed only from their cultural dimension, solely taking into account their representations, their behavioral models, the means by which they organize their relations? How can we get the humanities to integrate this evidence that social systems can only exist because they are rooted in a biological reality: that of bodies and that of the members?

Raynaut's words call our attention to the risk of omnipotence which is typical of the unidisciplinarity. One of the relationship difficulties that exist between health professionals and anthropologists is the temptation from the latter to transform medicine, as well as health activities only as social or discourse evidence. When this happens, we see disregard of social sciences from technique, this practical art that makes the human being recreate nature. Analyses of health and 
ailments as social facts - taking no notice of the biological essence of phenomena - produce the same reductionist perspective that medicine has of social phenomena - only in reverse.

In order to interact in partnership, the anthropology of contemporary health needs to feel challenged by the criticism of epidemiologists and of practicioners ${ }^{25}$, theoretically admitting (since in practice, the anthropologists know and feel it) that human beings are composed of spirit and body and that social wholeness are based on the biological reality of bodies. This note might sound obvious if not for the proliferation of a type of scientific production that naïvely uses phenomenological, symbolic interactionist and constructivist models, making people's speeches the truth about their own problems. Scholars that use such approaches superficially or in a reduced manner, analyze representations, relations and the social construction of health and ailment situations as if they were whole, leading to query from the medical areas and from epidemiology as to the need, the origin and the scientificity of their findings.

It is necessary to highlight that in health/ailment phenomena interpretations, the anthropologists are seen as the "readers of reality" and that, within a hegemonic model, the predominance is of the "biomedical reading". Legitimacy of anthropological findings by biomedicine with all its implications (and vice-versa) occurs as a kind of tacit agreement between the agents involved, the institutions, practices, relations and ideas. From the anthropological point of view this agreement is expressed in the respect for the important and irreplaceable role played by scientific medicine in contemporary society. From the biomedical point of view, on the other hand, it is expressed by accepting and valuing the idea that the population - regardless of whether one considers only those who use the public health and medical system, or those who use combined means of treatment, regardless of whether they only use alternative or traditional therapeutics - possesses rationality. In this meeting with alterities (which brings in itself the ethical foundation of relations and of action) one can see the understanding of the humanization of technique which, can only make sense in the health area if it is to improve the life quality of people. Thus, understanding that the health area is a pluri-disciplinary field in dispute for power and legitimacy 26,27 , between the medical paradigm (hegemonic for all the health science professions) and the anthropology, there will always be possible relations: complementary, conflictuous or of rejection, depending on the context, the problems and the agents that take part in the interaction. However, it is the responsibility of the field of anthropology to call attention to the essential characteristic of intersubjectivity and empathy with the essential values in the health sector.

Ethical dilemmas in anthropological research

Field research, the place where all ethnological career begins, is mother and breastfeeding milkmaid of doubt, a philosophical attitude by excellence.This anthropological doubt does not consist only of knowing that one knows nothing, but of resolutely exposing what one thought was known and their very ignorance to the insults and the denials that affect the ideas and the dearest habits to those that can refute them at the highest level ${ }^{28}$.

Problems of interaction between

researcher and social agents

in the field research

At this point, I intend to challenge the relationship of anthropologists and researchers (who have worked with qualitative research) with their field interlocutors. Nothing is simple and everything is complex in this relationship. In recent conversation with people from a slum, I heard the following expression: "researchers are people's 'chupa-cabra'. They research, take their conclusions, publish, improve in their careers and the people continue in their poverty conditions". Chupa-cabra is a creature believed to inhabit part of the Americas. It is mostly associated to Puerto Rico, Mexico and the even in the Latin American communities of the United States. Its name literally means 'goat sucker' since the creature is said to drink the blood of livestock. Would the awareness development of rights make it even more difficult for the investigator to approach their empirical field?

In the researcher - researched social group relationship, the critical observations of Social Sciences reach two levels of questions, both brining relevance to the problematic characteristic of interaction. On the one hand, there are several theories that emphasize the inequality situation in which interviews take place, leading the critics to state that the researcher's work is of domination and of a 'reproductivist' nature. On the other hand, in opposition to the first view, there are scholars that highlight that, from a cultural per- 
spective, interaction is necessary to empirical research, which is intrinsically conflictuous, but experienced within a spirit of freedom, not of necessity. For this reason, the latter consider that both researchers and researched are responsible for the product of their relations and that the quality of unveiling and of social understanding depends of both.

The basic premise for reflection, in both cases, is that human interaction in an interview situation, for example, cannot simply be considered a work of data collection. It will always constitute an intersubjective relationship in which information provided by subjects can be profoundly affected by the nature of the meeting itself.

Viewing the research situation as a peculiar expression of domination

The focus of the debate is the unequal exchange among social agents. This certainly occurs and under several perspectives: it is not the interviewee that takes the initiative; the actual research objectives are usually unknown to them; their chances of taking any initiative in relation to the theme is very little; the researcher is the one directing, controlling and guiding what will be said, besides being the person controlling turns, even when they try to make the interviewee feel comfortable. The nice and benevolent attitude showed by the scholar minimizes the impact, but does not reverse the situation of inequality between interlocutors. Even in the so-called 'participative research' and 'action research' these issues can be placed, though less vehemently.

Thus, social research would be a prisoner of labor division in capitalist society, by means of which, the researcher, in an institutional position of power, takes on the right to question the other, the society and its structural and organizational forms. Within this view, the subject/object (the interviewee) would produce material that is ultimately explored by their domineering peers (the researchers, in this case). This is, for example, Kandel's ${ }^{29}$ opinion: “Those investigated are faced with objective frames of reference with which they are (most of the times) unfamiliar. Reciprocity, if any, (such as in the right to question the questioner) is granted".

View of the research situation in the context of general production relations

The group that puts the enclosed circle of reproductivist reflection into perspective and criti- cizes it argues that if a piece of empirical research is included in the system of class domination, materialized in the scholars' roles, this situation cannot be withdrawn from the analyzed society. Therefore, looking at each particular research situation as domineering will not promote any practical consequence besides that of provoking a scientific stand still. Secondly, these sociologists of science argue that it is possible to carry out investigations with clear social, strategic objectives aimed at better understanding problems, improving services, evaluating programs of social intervention and other social actions ethically worthy.

Within this point of view, one considers that social researchers need to take into account that in fact, the practice of empirical social research is carried out in a contradictory context, where social asymmetric forms are reproduced, since scholars have access to certain types of actual and symbolic legacy from which a great number of people are excluded. Even if their interlocutors are from the same social class, theoretical reflection is far more familiar to the researcher than to their interviewees. Recognizing this does not mean that one needs to stop carrying out investigations, since the mechanisms of inequality and dissymmetry within society are much broader and complex, and are present in all kinds of relationships. It is necessary, however, to more clearly admit to oneself what the meaning of the investigation is - especially when it comes to the health area, where researchers are dealing with life and death -, thus attempting to provide solutions to the population's problems. By the same token, it is necessary to emphasize the means and proposals by which the information provided, the situations created and the alliances reflect the interests of those interviewed.

\section{Problems intrinsic}

to social interactions in fieldwork

Some authors have investigated field situations with intrinsic concern with the action of researching itself, thus producing a type of epistemology about the production conditions of social knowledge. Generally they are anthropologists that evidence the shakiness of the philosophical concept of scientific truth, from their empirical experience, and of difficulties found both in the participative observation and in interviews. They demonstrate the insertion in the "other's" world and challenge the pretentious objectivity, clarity and transparency in research 
situation. They evidence that social reality is a world of shades and light in which all the actors involved reveal and hide their group secrets. Instead of the passivity characteristic that the reproductivist and positivist theories, from different points of view, allow these agents (understanding, symbolic interactionists and phenomenologists) these researchers understand them as part of the active movement during the whole process of contact with the researcher.

Examples of these kinds of researchers are Goffman $^{30,31}$ and Berreman ${ }^{32}$ who designed rich, and plastic reflection, full of detail on the researcher/researched exchange. Both used theater images to show that this pair simultaneously constitutes actors and audience in the setting up of a unique show: their interrelation is mediated by specific cultural codes and by the private interests that both try to preserve and project.

On the relationship of the interviewer and their informants, Goffman ${ }^{31}$ states that: We often discover a division between the interior region - where representation is part of a pre-prepared routine; the external region - where representation is presented. Access to these regions is controled so as to stop the audience to see the behind the scenes and that foreigners have access only to a representation that is set for them.

Goffman's words, which appear in several of his works on total institutions and stigmas, are confirmed by Berreman's ${ }^{32}$ reflections on the difficulties of having access to information in ethnographic research in a Himalayan community. Berreman $^{32}$ socializes his experience describing them in images. He calls the "interior region" the most intimate part of the experience with the community. This region can be broader or stricter, he says, but all groups save their secrets, their official side, and all of them have a daily behavioral strategy. This internal cohesion occurs because, even if internally a group may experience many differences and conflicts, their existence depends on a certain degree of consensus, familiarity and solidarity which implies in sharing meaning, secrets, forbidden zones and also sharing what can and what cannot be said. In the same perspective as Berreman $^{32}$, Goffman's ${ }^{29}$ statement is clarifying when he says that there are few activities or daily relations in which agents are not involved in the hidden practices incompatible with the impressions that they seek to cause.

Because of this contingency of the interior region - from both parts -, there will always be a game, in any situation of field work, between the researcher - who is getting in touch and the speech and the behavior of their interlocutors. The latter always intends to keep a secret about the "interior region" (concept used by Berreman) or to have "control over impressions" (expression used by Goffman) that they provoke. This control is a basic aspect, inherent to interaction. For this reason, it is important that every social investigator knows that no group will say the whole truth about a social reality. There will always be a "control of impressions" and the safeguarding of the "interior region".

Berreman $^{32}$ insists that both agents in research (interviewer/interviewee), in a situation of interaction, brief as it may be, act by judging the motives and attributes that the others bring; defining the situation and the image they wish to project.

Therefore, there is no possibility of clarity or total transparency, as there is no scientific neutrality.

Dilemmas of the process

of participative observation

People that introduce the researcher in the field are (just as the researcher themselves) responsible for their images, as well as for all the doors that might be open or be shut. Accumulated experience shows that the profile of interlocutors and the quality of data gathered are related to the impact of the researcher's entry and introduction $^{24}$. However, their sensitivity and sympathetic ability in the field may decrease the initial impacting aspects. In the specific situation of research, empathy is at stake, as is the ability to observe and the researcher's acceptance - which cannot be changed into a practical recipe.

A second moment of insertion (here understood only for analytical purposes) is that of researcher's role definition ${ }^{18}$ within the group where they are being integrated. The actual roles that the researcher will play will vary according to the situation of research. Actually, in terms of groups elected, the researcher is less observed for the logical basis of their studies, and much more for their personality and behavior. Those who introduce them in the field and their interlocutors want to know if they are "good people", if they will not "harm the group", if they will not betray "their secrets" and their strategies for solving life problems.

There are multiple situations of research. However, as a rule of thumb, the researcher's image is constructed only in partial collaboration with them, since the image that they project rever- 
berates in the group by the references that the group has, within their specific cultural standards. By the same token, the image that the researcher builds of the group depends of the people with whom they relate. Thus, both sides build images that will always be incomplete and imprecise ${ }^{18}$.

Leaving the field is also a crucial moment. Interpersonal relations that are developed during the research are not automatically undone with the conclusion of activities planned. There is an informal "contract" of favors and of loyalty that cannot be abruptly broken lest there be deception: investigators work with people, therefore, with relations and with affection. There are not recipes for this moment, but some questions can be asked and answered by the researcher: what will relations that follow the field work be like? What is the commitment of the researcher with the group as far as primary data collected may be, as well as their scientific uses and the means by which they will be returned? In short, leaving the field involves ethical and practical problems. Intersubjective relations that area created can contribute to define the type of moment when the break is necessary from more intense relations, as well as a plan for possible and desirable continuity. However, above all, the ethicak commitment remains that the research must result in benefic for the society and, if applicable, for the group that accepted to take place in the research ${ }^{18}$.

Denzin $^{33}$ insists that, in comparison to scientists that work with surveys, the field research that uses participative observation is freer from losses, since they are not necessarily prisoners of a rigid data collecting instrument or hypotheses testing prior rather to during the research process. The flow which is bound to the nature of participative observation allows the researcher the possibility of using, at the same time, the data provided by surveys. As the observer deals with the group, they can take from their script questions that they realize may be irrelevant from the interlocutors' points of view; they can also understand aspects that become evident little by little, an impossible situation for a researcher who works with closed questionnaires which are previously standardized. Participative observation assists, therefore, in the linking of facts and their representations, and to unveil contradictions between norms and rules, and the practices experienced in the daily lives of the group. It is absolutely impossible to ask people to accept being observed. This procedural field dynamics denies the formalities of instruments required by Ethical Committees.
In terms of objectivity, by opposing what the positivists call the impressionism of subjectivity, Cicourel $^{34}$ comments that the higher the observer's participation, the greater the risk of their involvement, but, at the same time, the greater the possibility of their being able to penetrate the "interior region" of the group. This author highlights that objectivity control of data obtained via participative observation must be carried out with critical revisions of the field work, by means of the explanation of the procedure adopted and of the different roles played by the members of the researched group and of the researcher.

In this sense, criteria used for trustworthiness meet those of ethical behavior requirements, which must be part of every research, making the information sources explicit, as well as the context in which the research was carried out, both from the institutional point of view, the relationship between researched and their interlocutors, besides the situation and the work conditions in the field. Information on the conditions of research fulfillment is part of the contextualized understanding of the object of study.

I conclude this paper by highlighting that difficulties faced by researches to enter the field cannot be thought only as challenges for improving research techniques. There are difficulties that are typical of this work and that must be objects of reflection and of planning as part of the knowledge construction strategy within an ethical posture in which the rights of interlocutors and of researchers are preserved. In this sense, there is nothing a priori determined, even when there are procedures that are approved by the ethical committees.

\section{Questions on ethics}

I have had a few modest objectives with this paper:

- To show that there are contributions from Anthropology with which we can think ethics in research with human beings. Agreeing with Neves ${ }^{5}$, I can say that they fundamental contribution is its intrinsic adhesion to the unicity of the subject and to its relational characteristic - which is expressed in the subjectivity and in its ability to demonstrate solidarity and universality of what I here call fundamental human equality.

- To evidence the many yet unsolved difficulties in anthropological practices, especially in the researcher - interlocutors relationship, which does 
not allow us to take a leading position in terms of ethical issues that are asked us and that go against issues of intersubjectivity and interests.

- I have tried to fundament this paper on philosophical bases that seem to support the two paradigms from which different views on ethics in research derive: the pragmatic and principalist and the personalist and communicative. The ethics of science and technology in which one will find ethics in research cannot be mediated by current standardized procedures.

- I have read many works that currently exist on the controversies of the Ethical Commissions set up to respond to biomedical research challenges as to anthropological and qualitative investigations. From all these works, it is possible to derive at the same time the broad sense of the meaning of ethics, the broadened view of responsibilities that are not condensed in instruments evaluated by the ethical commission. Most of them highlight not only ethics within the casuistics of a certain research, but also of the scientific community relationship with society, of the institutional relationships with policy makers, researchers and students, and also, the social scien- tists action within their research field, as well as outside the field.

- Finally, I have no doubt that, in the specific case of the evaluation of our researches, it is necessary to provide criteria to those who will be judging them. But I take a stronger stand stating that we should produce a kind of rationale, followed by guiding elements for evaluators, submitting this proposal (which could be standardized) to public debate. Otherwise, we will continue to have that same that is happening, leading to a kind of complacent cynicism from the behalf of qualitative researchers that, having to submit to current Ethical Commissions, break the philosophical and practical principles of a great deal of the research in their areas. For example: to provide the exact number of field interlocutors; write up an instrument requiring those who are going to be observed for their consent, define closed instruments for investigation and for observation, among others. As Neves ${ }^{5}$ very well concludes, in Latin America, the principalist and pragmatic Anglo-American norm and European personalist and humanistic concerns are in conflict. However, the one that is being enforced is the former. 


\section{References}

1. Guerriero ICZ. Aspectos éticos das pesquisas qualitativas em saúde [dissertação]. São Paulo (SP): Faculdade de Saúde Pública; 2006.

2. Victora C, Oliven RG, Oro AP. Antropologia e ética: o debate atual no Brasil. Niterói: EdUFF; 2004

3. Social Science and Humanities Research Ethics Special Working Committee. Giving voice to the spectrum. 2004 [cited 2006 May 7]; (about 110 p.). Available from: http://www.pre.ethics.gc.ca

4. The Indian Committee for Ethics in Social Science Research in Health. Ethical guidelines for social research in health. 2001. [cited 2006 May 7]; (about 16 p.) Available from: http//www.hsph.Harvard.edu/ bioethics/guidelines/ethical/html

5. Neves MCP. A fundamentação antropológica da bioética. [cited 2006 Jun 29]; (about 10 p.). Available from: http//www.portalmedico.org.br/revista/ bio1v4/fundament.html

6. Gadamer H. Verdade e método. Petrópolis: Editora Vozes; 1999.

7. Habermas J. Teoría de la acción comunicativa. Tomos I y II. Madrid: Taurus Editorial; 1987.

8. Apel KO. Transformação da Filosofia. São Paulo: Editora Loyola; 2000.

9. Lévinas E. Totalidade e Infinito. Lisboa: Lisboa Edições 70; 1998 .

10. Geertz C. A interpretação das culturas. Rio de Janeiro: Editora Zahar; 1978.

11. Herzlich C. Santé et maladie. Paris: La Haye-Mouton; 1983.

12. Herzlich C, Pierret J. Malades d'hier, malades d'aujourd'hui. Paris: Editions Payot; 1984.

13. Kleinman A. Patients and Healers in the context of cultures. An exploration of borderland between anthropology and psychiatry. Berkeley: University of California Press; 1980.

14. Kleinman A. Concepts and models for the comparison of medical systems as cultural systems. Social Sciences and Medicine 1978; 12:85-93

15. Lévy-Srauss C. Introdution à l'ouevre de Marcel Mauss. In: Marcel Mauss: sociologie et anthropologie. Paris: Presses Universitaire de France; 1950. p. I-XXX.

16. Lévy-Strauss C. Structural anthropology. New York: Basic Books Inc Publishers; 1963.

17. Mauss M. Sociologie et Anthropologie. Paris: Presses Universitaires de France; 1950.

18. Minayo MCS. O desafio do conhecimento. Pesquisa qualitativa em saúde. São Paulo: Editora Hucitec; 2004.
19. Thomas W. The definition of situation. In: Coser LA, Rosemberg B, editors. Sociological Theories: a book of readings. Toronto: Mcmillan Company; 1970. p. 245-247.

20. Schutz A. Commonsense and scientific interpretations of human action. Hague: Martinus Nijhoff; 1982.

21. Nunes ED. As ciências sociais e saúde na América Latina: tendências e perspectivas. Washington: Opas; 1985.

22. Sfez L. La santé parfaite. Critique d'une nouvelle utopie. Paris: Éditions du Seuil; 1997.

23. Atlan H. $O$ útero artificial. Rio de Janeiro: Editora Fiocruz; 2006.

24. Malinowski B. Malinowski. Coleção Os Pensadores. São Paulo: Editora Abril Cultural; 1978.

25. Raynaut C. Interdisciplinaridade e promoção da saúde: o papel da antropologia. Algumas idéias simples a partir de experiências africanas e brasileiras. Revista Brasileira de Epidemiologia 2002; 5(Supl.1).

26. Bourdieu P. Ésquisse d'une théorie de la practique. Paris: Librairie Droz; 1973.

27. Bourdieu P. O poder simbólico. São Paulo: Editora Difel; 1989

28. Lévy Strauss C. Aula Inaugural. In: Zaluar A, organizadora. Desvendando máscaras sociais. Rio de Janeiro: Editora Francisco Alves; 1975. p.211-214.

29. Kandel L. Reflexões sobre o uso de entrevista, especialmente a não-diretiva e sobre pesquisas de opinião. Épistemologie Sociologique 1972; 13:25-46.

30. Goffman E. The presentation of self in everyday life. New York: Doubleday Co; 1959.

31. Goffman E. Strategic interaction. A fascinating study of the espionage games people play. New York: Ballantine Books Co; 1975.

32. Berreman G. Por detrás de muitas máscaras. In: Zaluar A, organizadora. Desvendando máscaras sociais. Rio de Janeiro: Editora Francisco Alves; 1975. p. 123-177.

33. Denzin NK. The research act. Chicago: Aldine Publishing Co; 1979.

34. Cicourel A. Method and measurement in sociology. New York: The Free Press; 1969.

Artigo apresentado em 08/05/2007

Aprovado em 10/07/2007

Versão final apresentada em 10/07/2007 